\title{
Exposure to the COVID-19 News on Social Media: Psychological and Self-reported Behavioural Responses Among Iranian Adults
}

\section{Parisa Mokhtari-Hesari}

Iranian Institute for Health Sciences Research

Hossein Yarmohammadi

Iranian Institute for Health Sciences Research

Mehdi Rafiei Bahabadi

Iranian Students' Polling Agency

Fatemeh Naghizadeh Moghari

Iranian Institute for Health Sciences Research

\section{Farzaneh Maftoon}

Iranian Institute for Health Sciences Research

Mahmoud Tavousi

Iranian Institute for Health Sciences Research

Hedyeh Riazi

Shahid Beheshti University of Medical Sciences School of Nursing and Midwifery

Ali Montazeri ( $\nabla$ montazeri@acecr.ac.ir)

Iranian Institute for Health Sciences Research https://orcid.org/0000-0002-5198-9539

\section{Research}

Keywords: COVID-19, Anxiety, Fear, Behavior change, News, Social media

Posted Date: May 19th, 2021

DOl: https://doi.org/10.21203/rs.3.rs-518988/v1

License: (c) (1) This work is licensed under a Creative Commons Attribution 4.0 International License. Read Full License 


\section{Abstract}

Background: Exposure to news on coronavirus disease 2019 (COVID-19) pandemic is inevitable. This study aimed to explore associations between exposure to COVID-19 news on social media and psychological and behavioral consequences among Iranians.

Methods: This was a telephone-based survey carried out in April 2020 in Iran. Iranian adults aged 18 and over were randomly selected from the postal codes and using their mobile phones. A self-designed questionnaire was administered to collect data on participants' characteristics and questions to address their psychological and behavioral responses regarding the COVID-19 pandemic. A multivariate logistic regression model was performed to assess the relationship between anxiety, fear, and behavioral responses and independent variables including exposure to news.

Results: In all 1563 adults participated in the study. The mean age of respondents was $39.17 \pm 13.5$ years. Moderate to high-level anxiety was reported by $55.4 \%$ of participants, while fear of being affected by coronavirus was reported by $54.1 \%$. Overall $88 \%$ reported that they changed their behaviors to some extent. Exposure to the COVID-19 news on social media was by far the most influencing variable on anxiety (OR= 2.21, 95\% Cl: 1.62-3.04; $\mathrm{P}<0.0001)$, fear $(\mathrm{OR}=1.95,95 \% \mathrm{Cl}: 1.49-2.56 ; \mathrm{P}<0.0001)$, and change in health behaviors $(\mathrm{OR}=2.02,95 \% \mathrm{Cl}$ : $1.28-3.19 ; \mathrm{P}=0.003)$ in the regression model. While independent variables did not show significant associations with anxiety and behavior change, the fear of being infected by the COVID19 was associated with the female gender and some socio-economic characteristics of the participants.

Conclusion: Although exposure to the COVID-19 news on social media seemed to be associated with excessive anxiety and fear among people, it also, to some extent, positively has changed people's health behaviors towards preventive measures.

\section{Introduction}

The outbreak of COVID-19 had a detrimental effect on global healthcare systems with a rapid and profound impact on every aspect of human life [1], from the way people socialize, to work, live, shop, and plan for the future [2]. In addition to the global spread of the virus itself, another sort of pandemic developed misleading rumors and disinformation were shared through online media, including all the larger social media, video, and messenger platforms such as Twitter, Facebook, Instagram, WhatsApp, and YouTube [3]. Scientifically unfounded speculations on potential causes and cures made the rounds, causing confusion and risky behavior among people who followed misleading and false recommendations [4].

It is well-documented that pandemics can lead to heightened levels of stress and consequently anxiety that is a common response to any stressful situation. Recent evidence suggests that individuals who are kept in quarantine, experience significant distress which can be appeared in the form of anxiety, anger, confusion, and post-traumatic stress symptoms [5]. The media has the most influential power either 
negative or positive on people's knowledge during pandemics. This technology has been reporting continuously across borders to keep all informed about the pandemic situation and now this has led to a massive and different public reaction. As a result, the number of information people obtain about the COVID-19 from the media daily is raising a lot of concern for people leading to heightened, for example, levels of anxiety or concern [6].

The psychological and behavioral responses of the public are expected to largely influence the personal protective measures and eventually the clinical outcome [7]. Mental health professionals need to provide the necessary support to those exposed and to those who deliver care. To help the outbreak management of COVID-19 in Iran, there is an urgent need to understand the public's awareness and attitudes towards COVID-19. This study aimed to assess the psychological and behavioral response to the news of the COVID-19 pandemic among the Iranian adult population.

\section{Methods}

\section{Design and participants}

The present study was a telephone-based cross-sectional survey conducted during the COVID-19 pandemic in April 2020. A sample of Iranian adults aged 18 years and above were randomly selected from the list of post codes and using their mobile phones. All provinces in Iran were defined as the strata and proportional to the population of each province the required sample size was drawn. The primary sampling unit consisted of individuals living in the province. All participants were made aware of the study protocol, and verbal informed consent was obtained.

\section{Sample size}

The sample size was based on the following formula:

$n=Z^{2} P(1-P) / d^{2}$

Considering $Z=1.96, P=0.5$ (assuming $50 \%$ would use social media), and $d=3 \%$ (precision), a sample size of 1067 participants was estimated. Considering the design effect (Deff $=1.5$ ) recruiting a sample of 1600 was thought. However, in practice 1563 adults were included in the study.

\section{Measurement}

A self-designed questionnaire with two sections was administered. The socio-demographic information included the recording of age, gender, marital status, education, economic status, and occupation. In addition, six items were included to address people's exposure to news on the COVID-19 pandemic (3 items), and three items were asked to measure psychological and behavioral responses (hand washing, wearing face mask and practicing social distancing). Each item was rated on a 5-point Likert scale.

\section{Data collection}


At the begging of the phone interview, people were asked for consent. After they accepted to take part in the survey, the interviewers asked the questions one by one and filled in the demographic details and the six study questions. All interviewers were trained for this specific study to assure that ethical principles and consistency in data collection were considered.

\section{Statistical analyses}

Descriptive statistics were used to report the data including mean, standard deviation, and frequency, and percentage. To assess the association between dependent variables (anxiety, fear, and self-reported behavior change) and exposure to news on COVID-19 both univariate and multivariable logistic regression analysis was performed. The results were presented as odds ratio and $95 \%$ confidence intervals. All statistical analyses were performed using R software (ver. 11, College Station, Texas, USA).

\section{Results}

\section{Participants}

In all 1563 adults participated in the study. The mean age was $39.17 \pm 13.5$ in this study. It can be seen that approximately, half of the sample population was in the middle economic status, while the vast majority of individuals were high school-educated adults $(60.1 \%)$ and university or college-leveled institutes (35.3\%). The description of sociodemographic variables is summarized in Table 1. 
Table 1

Characteristics of Iranian adults who participated in the study $(\mathrm{n}=1563)$

\begin{tabular}{|ll|}
\hline Variables & No. (\%) \\
\hline Age $($ Mean \pm SD) & $39.17 \pm 13.5$ \\
\hline Gender & \\
\hline Female & $775(49.6)$ \\
\hline Male & $788(50.4)$ \\
\hline Marital status & \\
\hline Single & $342(21.9)$ \\
\hline Married & $1160(74.3)$ \\
\hline Divorced/widowed & $61(3.8)$ \\
\hline Economic status & \\
\hline Poor & $322(24.5)$ \\
\hline Intermediate & $619(47.2)$ \\
\hline Very good & $372(28.3)$ \\
\hline Education & \\
\hline Illiterate & $74(4.7)$ \\
\hline Secondary & $428(27.3)$ \\
\hline Higher & $511(32.7)$ \\
\hline Employment status & \\
\hline Unemployed & $64(4.4)$ \\
\hline Housewife & $516(35.5)$ \\
\hline Student & $95(6.5)$ \\
\hline Employed & $687(47.3)$ \\
\hline Retired & $91(6.3)$ \\
\hline
\end{tabular}

\section{Descriptive findings}

Moderate to high-level of anxiety was reported by $55.4 \%$ of participants and this was $54.1 \%$ for fear of being affected by coronavirus disease, while $88 \%$ of people reported that they have changed their 
behaviors. The detailed results are shown in Table 2.

Table 2

Descriptive statistics for the study measures

\begin{tabular}{|c|c|c|c|c|c|}
\hline & Not at all & Slightly & Moderately & Considerably & $\begin{array}{l}\text { A great } \\
\text { deal }\end{array}$ \\
\hline & No. (\%) & No. (\%) & No. (\%) & No. (\%) & No. (\%) \\
\hline $\begin{array}{l}\text { To what extent do you follow } \\
\text { the statistics and information } \\
\text { on COVID-19? }(n=1559)\end{array}$ & $70(4.5)$ & $307(19.7)$ & $342(21.9)$ & $539(34.6)$ & $301(19.3)$ \\
\hline $\begin{array}{l}\text { To what extent do you follow } \\
\text { formal news on COVID-19 } \\
\text { released by the state? }(n= \\
1560)\end{array}$ & 153(9.8) & $447(28.7)$ & $306(19.6)$ & $477(30.6)$ & 177(11.3) \\
\hline $\begin{array}{l}\text { To what extent do you follow } \\
\text { the news on COVID-19 on } \\
\text { social media? }(n=1561)\end{array}$ & $517(33.1)$ & $379(24.3)$ & $204(13.1)$ & $340(21.8)$ & $121(7.8)$ \\
\hline $\begin{array}{l}\text { To what extent exposure to the } \\
\text { news on COVID- } 19 \text { made you } \\
\text { feel anxious and worry? }(\mathrm{n}= \\
1044)\end{array}$ & 137(13.1) & $328(31.4)$ & $211(20.2)$ & $261(25.0)$ & $107(10.2)$ \\
\hline $\begin{array}{l}\text { To what extent do you fear } \\
\text { being infected with COVID-19? } \\
(n=1561)\end{array}$ & $375(24.0)$ & $342(21.9)$ & $268(17.2)$ & $324(20.8)$ & $252(16.1)$ \\
\hline $\begin{array}{l}\text { To what extent fear of being } \\
\text { infected provoked you to stick } \\
\text { to healthy behaviors? ( } \mathrm{n}= \\
\text { 1188) }\end{array}$ & $29(2.4)$ & $113(9.5)$ & $136(11.4)$ & $504(42.4)$ & $406(34.2)$ \\
\hline
\end{tabular}

\section{Feeling of anxiety}

In the multivariate logistic regression model, experience of anxiety significantly was associated with exposure to news on social media $(\mathrm{OR}=2.21,95 \% \mathrm{Cl}: 1.62-3.04) ; \mathrm{P}<0.0001)$. The results are shown in Table 3. 
Table 3

The results obtained from logistic regression analysis for feeling anxiety

\begin{tabular}{|c|c|c|c|c|}
\hline & \multicolumn{2}{|c|}{ Univariate analysis } & \multicolumn{2}{|c|}{ Multivariate analysis } \\
\hline & OR $(95 \% \mathrm{Cl})$ & $\begin{array}{l}\mathrm{P}- \\
\text { value }\end{array}$ & OR $(95 \% \mathrm{Cl})$ & $\begin{array}{l}\mathrm{P} \text { - } \\
\text { value }\end{array}$ \\
\hline Age & $\begin{array}{l}0.99(0.98- \\
1.01)\end{array}$ & 0.68 & 0.99 & 0.43 \\
\hline \multicolumn{5}{|l|}{ Gender } \\
\hline Female & 1.0 (ref.) & & 1.0 (ref.) & \\
\hline Male & $\begin{array}{l}1.33(1.03- \\
1.69)\end{array}$ & 0.024 & $\begin{array}{l}1.44(0.93- \\
2.24)\end{array}$ & 0.10 \\
\hline \multicolumn{5}{|l|}{ Marital status } \\
\hline Single & 1.0(ref.) & & 1.0 (ref.) & \\
\hline Married & $\begin{array}{l}1.05(0.79- \\
1.39)\end{array}$ & 0.71 & $0.85(0.54,1.34)$ & 0.48 \\
\hline Divorced/widowed & $\begin{array}{l}1.33(0.62- \\
2.85)\end{array}$ & 0.46 & $1.32(0.45,3.9)$ & 0.61 \\
\hline \multicolumn{5}{|l|}{ Economic status } \\
\hline Very good & 1.0 (ref.) & & 1.0 (ref.) & \\
\hline Intermediate & $0.82(0.61-1.1)$ & 0.18 & $0.94(0.61,1.45)$ & 0.79 \\
\hline Poor & $\begin{array}{l}0.93(0.83- \\
0.36)\end{array}$ & 0.66 & $0.95(0.57,1.56)$ & 0.83 \\
\hline \multicolumn{5}{|l|}{ Education } \\
\hline Illiterate & 1.0 (ref.) & & 1.0 (ref.) & \\
\hline Secondary & $\begin{array}{l}0.27(0.06- \\
1.35)\end{array}$ & 0.008 & $\begin{array}{l}0.74(0.36- \\
1.55)\end{array}$ & 0.42 \\
\hline Higher & $0.25(0.24,0.74)$ & 0.003 & $0.56(0.26,1.21)$ & 0.14 \\
\hline \multicolumn{5}{|l|}{ Employment status } \\
\hline Unemployed & 1.0 (ref.) & & 1.0 (ref.) & \\
\hline Housewife & $\begin{array}{l}0.74(0.41- \\
1.36)\end{array}$ & 0.34 & $\begin{array}{l}0.77(0.32- \\
1.85)\end{array}$ & 0.56 \\
\hline Student & $\begin{array}{l}1.15(0.62- \\
2.14)\end{array}$ & 0.65 & $0.65(0.25,1.72)$ & 0.56 \\
\hline
\end{tabular}

* Bold values are significant. 


\begin{tabular}{|c|c|c|c|c|}
\hline \multirow[b]{2}{*}{ Employed } & \multicolumn{2}{|c|}{ Univariate analysis } & \multicolumn{2}{|c|}{ Multivariate analysis } \\
\hline & $\begin{array}{l}0.73(0.35- \\
1.51)\end{array}$ & 0.4 & $\begin{array}{l}0.72(0.33- \\
1.57)\end{array}$ & 0.41 \\
\hline Retired & $\begin{array}{l}0.43(0.19- \\
0.98)\end{array}$ & 0.046 & $0.47(0.15-1.4)$ & 0.18 \\
\hline \multicolumn{5}{|c|}{$\begin{array}{l}\text { Exposure to information and statistics on } \\
\text { COVID-19 }\end{array}$} \\
\hline No & 1.0 (ref.) & & 1.0 (ref.) & \\
\hline Yes & $\begin{array}{l}1.05(0.75- \\
1.45)\end{array}$ & 0.78 & $0.94(0.57,1.55)$ & 0.83 \\
\hline \multicolumn{5}{|c|}{ Exposure to formal news about COVID-19 } \\
\hline No & 1.0 (ref.) & & 1.0 (ref.) & \\
\hline Yes & $1.4(1.04-1.85)$ & 0.02 & $1.4(0.98-2.1)$ & 0.059 \\
\hline \multicolumn{5}{|c|}{$\begin{array}{l}\text { Exposure to COVID-19 news on social } \\
\text { media }\end{array}$} \\
\hline No & 1.0 (ref.) & & 1.0 (ref.) & \\
\hline Yes & $\begin{array}{l}2.31(1.78- \\
2.98)\end{array}$ & 0.0001 & $\begin{array}{l}2.21(1.62- \\
3.04)\end{array}$ & 0.0001 \\
\hline
\end{tabular}

\section{Feeling of fear}

Being female ( $p$-value $<0.001)$, intermediate economic status ( $p$-value $=0.049)$, being employed ( $p$-value $=0.047$ ), higher exposure to information and statistics on COVID-19 ( $p$-value $=0.011)$, exposure to formal news on COVID-19 ( $p$-value $=0.002$ ) and exposure to social media for updating on COVID-19 news ( $p$ value $<0.001)$ showed significant association with feeling of fear. The results are presented in Table 4. 
Table 4

The results obtained from logistic regression analysis for feeling fear

\begin{tabular}{|c|c|c|c|c|}
\hline \multirow[b]{2}{*}{ Characteristics } & \multicolumn{2}{|c|}{ Univariate analysis } & \multicolumn{2}{|c|}{ Multivariate analysis } \\
\hline & OR (95\% Cl) & $\begin{array}{l}\mathrm{P}- \\
\text { value }\end{array}$ & OR $(95 \% \mathrm{Cl})$ & $\begin{array}{l}\mathrm{P} \text { - } \\
\text { value }\end{array}$ \\
\hline Age & $\begin{array}{l}0.99(0.98- \\
1.001)\end{array}$ & 0.08 & $\begin{array}{l}0.99(0.98- \\
1.005)\end{array}$ & 0.25 \\
\hline \multicolumn{5}{|l|}{ Gender } \\
\hline Male & 1.0 (ref.) & & 1.0 (ref.) & \\
\hline Female & $\begin{array}{l}2.04(1.67- \\
2.5)\end{array}$ & $\hat{0.0001}$ & $\begin{array}{l}2.17(1.46- \\
3.22)\end{array}$ & $<.0001$ \\
\hline \multicolumn{5}{|l|}{ Marital status } \\
\hline Single & 1.0 (ref.) & & 1.0 (ref.) & \\
\hline Married & $\begin{array}{l}1.14(0.89- \\
1.45)\end{array}$ & 0.29 & $\begin{array}{l}1.22(0.82- \\
3.83)\end{array}$ & 0.32 \\
\hline Divorced/widowed & $\begin{array}{l}1.64(0.94- \\
2.9)\end{array}$ & 0.08 & $\begin{array}{l}1.79(0.84- \\
3.83)\end{array}$ & 0.21 \\
\hline \multicolumn{5}{|l|}{ Economic status } \\
\hline Very good & 1.0 (ref.) & & 1.0 (ref.) & \\
\hline Intermediate & $\begin{array}{l}0.75(0.57- \\
0.99)\end{array}$ & 0.042 & $0.73(0.51,0.99)$ & 0.049 \\
\hline Poor & $\begin{array}{l}0.86(0.63- \\
1.62)\end{array}$ & 0.32 & $0.89(0.6,1.32)$ & 0.57 \\
\hline \multicolumn{5}{|l|}{ Education } \\
\hline Illiterate & 1.0 (ref.) & & 1.0 (ref.) & \\
\hline Secondary & $\begin{array}{l}0.87(0.65- \\
1.16)\end{array}$ & 0.33 & $0.9(0.64,1.49)$ & 0.91 \\
\hline Higher & $\begin{array}{l}1.06(0.79- \\
1.42)\end{array}$ & 0.69 & $1.02(0.62,1.65)$ & 0.93 \\
\hline \multicolumn{5}{|l|}{ Employment status } \\
\hline Unemployed & 1.0 (ref.) & & 1.0 (ref.) & \\
\hline Employed & $\begin{array}{l}1.54(0.92- \\
2.61)\end{array}$ & 0.1 & $\begin{array}{l}2.05(1.01- \\
6.22)\end{array}$ & 0.047 \\
\hline
\end{tabular}

* Bold values are significant. 


\begin{tabular}{|c|c|c|c|c|}
\hline \multirow[b]{2}{*}{ Housewife } & \multicolumn{2}{|c|}{ Univariate analysis } & \multicolumn{2}{|c|}{ Multivariate analysis } \\
\hline & $\begin{array}{l}2.56(1.5- \\
4.36)\end{array}$ & 0.001 & $1.9(0.88-4.13)$ & 0.10 \\
\hline Student & $\begin{array}{l}1.96(1.03- \\
3.75)\end{array}$ & 0.04 & $\begin{array}{l}1.76(0.74- \\
4.23)\end{array}$ & 0.20 \\
\hline Retired & $\begin{array}{l}1.7(0.89- \\
3.27)\end{array}$ & 0.11 & $2.2(0.97-4.99)$ & 0.058 \\
\hline \multicolumn{5}{|c|}{$\begin{array}{l}\text { Exposure to information and statistics on } \\
\text { COVID- } 19\end{array}$} \\
\hline No & 1.0 (ref.) & & 1.0 (ref.) & \\
\hline Yes & $\begin{array}{l}1.66(1.26- \\
2.15)\end{array}$ & 0.0001 & $1.52(1.1-2.12)$ & 0.011 \\
\hline \multicolumn{5}{|c|}{ Exposure to formal news about COVID-19 } \\
\hline No & 1.0 (ref.) & & 1.0 (ref.) & \\
\hline Yes & $\begin{array}{l}1.86(1.47- \\
2.36)\end{array}$ & 0.0001 & $\begin{array}{l}1.62(1.20- \\
2.20)\end{array}$ & 0.002 \\
\hline \multicolumn{5}{|c|}{$\begin{array}{l}\text { Exposure to COVID-19 news on social } \\
\text { media }\end{array}$} \\
\hline No & 1.0 (ref.) & & 1.0 (ref.) & \\
\hline Yes & $\begin{array}{l}2.003(1.63- \\
2.46)\end{array}$ & 0.0001 & $\begin{array}{l}1.95(1.49- \\
2.56)\end{array}$ & $\hat{0} .0001$ \\
\hline
\end{tabular}

\section{Self-reported behavioral response}

The only factor that influenced behavior change was exposure to COVID-19 news on social media (OR = $2.02,95 \% \mathrm{Cl}: 1.28-3.19 ; \mathrm{P}=0.003)$. In fact, people reported that they took more preventive measures (hand washing, wearing face mask, social distancing) after exposure to COVID-19 news on social media. The results are reported in Table 5. 
Table 5

The results obtained from logistic regression for self-reported behavior change

\begin{tabular}{|c|c|c|c|c|}
\hline & \multicolumn{2}{|c|}{ Univariate analysis } & \multicolumn{2}{|c|}{ Multivariate analysis } \\
\hline & OR (95\% Cl) & $\begin{array}{l}\mathrm{P}- \\
\text { value }\end{array}$ & OR (95\% Cl) & $\begin{array}{l}\mathrm{P} \text { - } \\
\text { value }\end{array}$ \\
\hline Age & $\begin{array}{l}0.99(0.98- \\
1.01)\end{array}$ & 0.44 & $0.99(0.97,1.02)$ & 0.79 \\
\hline \multicolumn{5}{|l|}{ Gender } \\
\hline Female & 1.0 (ref.) & & 1.0 (ref.) & \\
\hline Male & $\begin{array}{l}1.6(1.12- \\
2.28)\end{array}$ & 0.009 & $\begin{array}{l}1.86(0.97- \\
3.54)\end{array}$ & 0.059 \\
\hline \multicolumn{5}{|l|}{ Marriage status } \\
\hline Single & 1.0 (ref.) & & 1.0 (ref.) & \\
\hline Married & $\begin{array}{l}1.19(0.79- \\
1.78)\end{array}$ & 0.41 & $1.15(0.6,2.20)$ & 0.67 \\
\hline Divorced/widow & $\begin{array}{l}1.24(0.46- \\
3.35)\end{array}$ & 0.67 & $1.01(0.26,3.82)$ & 0.98 \\
\hline \multicolumn{5}{|l|}{ Economic status } \\
\hline Very good & 1.0 (ref.) & & 1.0 (ref.) & \\
\hline Intermediate & $\begin{array}{l}0.78(0.51- \\
1.18)\end{array}$ & 0.24 & $1.31(0.78,2.41)$ & 0.26 \\
\hline Poor & $\begin{array}{l}0.49(0.18- \\
1.36)\end{array}$ & 0.17 & $0.91(0.48,1.68)$ & 0.75 \\
\hline \multicolumn{5}{|l|}{ Education } \\
\hline Illiterate & 1.0 (ref.) & & 1.0 (ref.) & \\
\hline Secondary & $\begin{array}{l}1.07(0.64- \\
1.8)\end{array}$ & 0.77 & $0.74(0.35,1.57)$ & 0.43 \\
\hline Higher & $\begin{array}{l}0.86(0.59- \\
1.7)\end{array}$ & 0.97 & $0.68(0.29,1.58)$ & 0.37 \\
\hline \multicolumn{5}{|c|}{ Employment status } \\
\hline Unemployed & 1.0 (ref.) & & 1.0 (ref.) & \\
\hline Housewife & $\begin{array}{l}2.39(1.17- \\
4.86)\end{array}$ & 0.016 & $2.16(0.69-6.7)$ & 0.18 \\
\hline Student & $\begin{array}{l}3.75(1.79- \\
7.86)\end{array}$ & $<.0001$ & $\begin{array}{l}2.12(0.61- \\
7.38)\end{array}$ & 0.23 \\
\hline
\end{tabular}




\begin{tabular}{|c|c|c|c|c|}
\hline \multirow[b]{2}{*}{ Employed } & \multicolumn{2}{|c|}{ Univariate analysis } & \multicolumn{2}{|c|}{ Multivariate analysis } \\
\hline & $\begin{array}{l}2.65(1.04- \\
6.75)\end{array}$ & 0.04 & $\begin{array}{l}2.44(0.90- \\
6.59)\end{array}$ & 0.07 \\
\hline Retired & $\begin{array}{l}0.43(0.69- \\
4.6)\end{array}$ & 0.23 & $\begin{array}{l}1.26(0.33- \\
4.83)\end{array}$ & 0.73 \\
\hline \multicolumn{5}{|c|}{$\begin{array}{l}\text { Exposure to information and statistics on } \\
\text { COVID-19 }\end{array}$} \\
\hline No & 1.0 (ref.) & & 1.0 (ref.) & \\
\hline Yes & $\begin{array}{l}1.4(0.91- \\
2.16)\end{array}$ & 0.12 & $\begin{array}{l}1.33(0.79- \\
2.558)\end{array}$ & 0.28 \\
\hline \multicolumn{5}{|c|}{ Exposure to formal news about COVID-19 } \\
\hline No & 1.0 (ref.) & & 1.0 (ref.) & \\
\hline Yes & $\begin{array}{l}1.93(1.32- \\
2.82)\end{array}$ & 0.01 & $\begin{array}{l}1.44(0.89- \\
2.32)\end{array}$ & 0.13 \\
\hline \multicolumn{5}{|c|}{ Exposure to COVID-19 news on social media } \\
\hline No & 1.0 (ref.) & & 1.0 (ref.) & \\
\hline Yes & $\begin{array}{l}2.11(1.45- \\
3.07)\end{array}$ & 0.0001 & $\begin{array}{l}2.02(1.28- \\
3.19)\end{array}$ & 0.003 \\
\hline
\end{tabular}

\section{Discussion}

This study showed a network of factors affecting anxiety, fear, and behaviour change during the COVID19 pandemic. Exposure to COVID-19 news had a significant relationship with both anxiety and fear, and also with health behaviour change.

\section{Anxiety}

Exposure to COVID-19 news was the only factor that had a significant relationship with anxiety. The impact of news on anxiety has been reported in previous studies too. In the cross-sectional study of Gao et al in China, there were high rates of anxiety and depression among the Chinese general adult population, and more exposure to social media was significantly associated with worsening anxiety/depressive disorders. Gao et al have suggested that the government should consider the adverse result of infodemic during the COVID-19 pandemic on people's mental health [8]. Ni et al in another crosssectional study in China have reported similar findings [9].

The current study did not assess the possible relationship between anxiety and the exposure time. A study from Bangladesh showed that more than 4 hours of using social media was related to its higher 
levels of anxiety [10]. Also, it is important to note isolation, quarantine, social distancing, and loneliness all could led to spending more hours in social media [11].

Although the current study did not show a significant relationship between most independent variables and anxiety, a study from Iran, ten percent of the study population showed anxiety symptoms that had an association with female gender, younger age, and experience of COVID-19 among family members or friends [12]. Similarly a study reported that anxiety and depression of the Iranian population were associated with female sex, cardiovascular diseases, smoking, and history of COVID-19 symptoms including fever, cough, and shortness of breath [13].

\section{Fear}

Different factors had a significant relationship with fear including female sex, middle economic status, being employed, following COVID-19 statistics released by the state, and exposure to news in social media. In the study of Mertens et al. in the Netherlands, using social media and anxiety were among the main factors affecting fear of COVID-19 [14]. Also, Lin et al reported similar findings in Hong-Kong where they reported that social media provoked fear in society [15].

Using the Fear of COVID-19 Scale [16] a study showed that the fear was significantly accompanied by psychological distress including anxiety, depression, and stress, and also with lower life satisfaction [17]. Similar findings have been reported in many other countries [18-21]. Aslam et al investigated the news headlines regarding the COVID-19 pandemic and their induced emotions. More than half of the headlines were accompanied by negative emotions while 30 percent of news evoked positive emotions [22].

\section{Behaviour change}

Social media was the only factor influencing health behaviour. Yousuf et al. have reported that using social media for a campaign of behaviour change, led to the improvement of hand washing and disinfecting. Also, it may be an effective way to prevent the spreading of fake news [23]. An online survey on American adolescents aged 13 to 18 years old showed that news monitoring was associated with greater social responsibility, more disinfecting, and attitudes about the greater severity of COVID-19 [24]. Therefore, it could be concluded that the adequate emphasis on the importance of COVID-19 without raising an ocean of disinformation, may improve people's responsibility and change their attitudes toward positive health behaviours including disinfecting frequently.

The study by Zhao et al. in the USA concluded a relationship between media trust and preventive health behaviours. Those Americans who trusted CNN more than Fox News, had a better engagement with behaviours such as washing hands, avoiding public places, or wearing masks [25]. This study shows that to what extent social media has importance in shaping knowledge, attitude, and behaviours during the COVID-19 pandemic and not only taking account of the media in psychological research is necessary, but also there should be an emphasis on the contents of it. Also, Tsai et al in the USA have reported that traditional news exposure combined with conservative ideology and trust in such social media raise a 
prejudice against Asians while those who followed left-wing social media and news, had lower prejudice. Interestingly those who had trust in social media and digital news together had lower prejudice [26].

Olagoke et al have reported that exposure to COVID-19 news had both positive and negative effects. The exposure was associated with behaviour change of self-protection against the virus, however it also was related to depressive symptoms [27]. This study demonstrated somehow a similar finding, as it proposes that exposure to COVID-19 news in social media was associated with both positive and negative effects. Although one hypothesis is that exposure leads to behaviour change through provoking anxiety and fear feelings, further studies need to investigate such relationship. But it seems besides the process of change in behaviour after exposure to COVID-19 mews, social media may be an opportunity to improve health behaviours.

\section{Limitations}

One limitation was that the fact that we did not ask participants how much they were spending on social media. This was a cross-sectional study in nature and thus could not indicate causality and the findings should be interpreted with caution.

\section{Conclusion}

The study findings showed that association exist between exposure to the COVID-19 news on social media and anxiety, fear, and behaviour change. Indeed, exposure to COVID news on social media should be balanced against harms and benefits.

\section{Abbreviations}

COVID-19: The Coronavirus Disease-2019

OR: Odds ratio

Cl: Confidence interval

\section{Declarations}

\section{Ethics approval and consent to participate}

The study protocol including obtaining verbal consent due to the COVID-19 pandemic was approved by the ethic committee of the Iranian National Institute for Medical Research Development (IR.NIMAD.REC.1399.297).

\section{Consent to publish}

Not applicable. 
Availability of data and materials

The data are available from the corresponding author.

\section{Competing interests}

The authors declare that they have no conflict of interests.

\section{Funding}

The Iranian National Institutes for Medical Research Development (NIMAD) funded the study.

\section{Authors' contributions}

$\mathrm{PMH}, \mathrm{HY}$ contributed to analysis and writing the first draft. MRB helped in sampling, recruitment, and data collection. FM and MT, and FNM helped in writing the proposal and administration of the project. HR critically reviewed the paper and contributed to the writing. AM designed the study, supervised the project, contributed to analysis and writing, provided the final manuscript and was the grant holder. All authors read and approved the final draft.

\section{Acknowledgment}

Research reported in this publication was supported by Elite Researcher Grant Committee under award number [996382] from the National Institutes for Medical Research Development (NIMAD), Tehran, Iran

\section{References}

1. Nicola M, Alsafi Z, Sohrabi C, Kerwan A, Al-Jabir A, losifidis C, et al. The socio-economic implications of the coronavirus pandemic (COVID-19): A review. International journal of surgery (London, England). 2020;78:185.

2. Lee SA, Mathis AA, Jobe MC, Pappalardo EA. Clinically significant fear and anxiety of COVID-19: A psychometric examination of the Coronavirus Anxiety Scale. Psychiatry Research. 2020:113112.

3. Boberg S, Quandt T, Schatto-Eckrodt T, Frischlich L. Pandemic populism: Facebook pages of alternative news media and the corona crisis-A computational content analysis. arXiv preprint arXiv:200402566. 2020.

4. Phillips T. Coronavirus misinformation is dangerous. Think before you share. The Guardian. 2020.

5. Brooks SK, Webster RK, Smith LE, Woodland L, Wessely S, Greenberg N, et al. The psychological impact of quarantine and how to reduce it: rapid review of the evidence. The Lancet. 2020.

6. Roy D, Tripathy S, Kar SK, Sharma N, Verma SK, Kaushal V. Study of knowledge, attitude, anxiety \& perceived mental healthcare need in Indian population during COVID-19 pandemic. Asian Journal of Psychiatry. 2020:102083. 
7. Frissen T, De Coninck D, Matthys K, d'Haenens L. Longitudinal Evidence of How Media Audiences Differ in Public Health Perceptions and Behaviors During a Global Pandemic. Frontiers in Public Health. 2020;8.

8. Gao J, Zheng P, Jia Y, Chen H, Mao Y, Chen S, et al. Mental health problems and social media exposure during COVID-19 outbreak. Plos one. 2020;15(4):e0231924.

9. Ni MY, Yang L, Leung CM, Li N, Yao XI, Wang Y, et al. Mental health, risk factors, and social media use during the COVID-19 epidemic and cordon sanitaire among the community and health professionals in Wuhan, China: Cross-sectional survey. JMIR mental health. 2020;7(5):e19009.

10. Hossain MT, Ahammed B, Chanda SK, Jahan N, Ela MZ, Islam MN. Social and electronic media exposure and generalized anxiety disorder among people during COVID-19 outbreak in Bangladesh: A preliminary observation. Plos one. 2020;15(9):e0238974.

11. Boursier V, Gioia F, Musetti A, Schimmenti A. Facing loneliness and anxiety during the COVID-19 isolation: the role of excessive social media use in a sample of Italian adults. Frontiers in Psychiatry. 2020;11.

12. Moghanibashi-Mansourieh A. Assessing the anxiety level of Iranian general population during COVID-19 outbreak. Asian journal of psychiatry. 2020:102076.

13. Ansari Ramandi MM, Yarmohammadi H, Beikmohammadi S, Hosseiny Fahimi BH, Amirabadizadeh A. Factors associated with the psychological status during the Coronavirus pandemic, baseline data from an Iranian Province. Caspian J Intern Med. 2020; 11 :484-494.

14. Mertens G, Gerritsen L, Duijndam S, Salemink E, Engelhard IM. Fear of the coronavirus (COVID-19): Predictors in an online study conducted in March 2020. Journal of Anxiety Disorders. 2020;74:102258.

15. Lin C-Y, Broström A, Griffiths MD, Pakpour AH. Investigating mediated effects of fear of COVID-19 and COVID-19 misunderstanding in the association between problematic social media use, psychological distress, and insomnia. Internet Interventions. 2020;21:100345.

16. Ahorsu DK, Lin C-Y, Imani V, Saffari M, Griffiths MD, Pakpour AH. The fear of COVID-19 scale: development and initial validation. International journal of mental health and addiction; In press

17. Satici B, Gocet-Tekin E, Deniz ME, Satici SA. Adaptation of the Fear of COVID-19 Scale: Its association with psychological distress and life satisfaction in Turkey. International Journal of Mental Health and Addiction; In press.

18. Abad A, da Silva JA, de Paiva Teixeira LEP, Antonelli-Ponti M, Bastos S, Mármora CHC, et al. Evaluation of fear and peritraumatic distress during COVID-19 pandemic in Brazil. Advances in Infectious Diseases. 2020;10(03):184.

19. Shigemura J, Ursano RJ, Morganstein JC, Kurosawa M, Benedek DM. Public responses to the novel 2019 coronavirus (2019-nCoV) in Japan: Mental health consequences and target populations. Psychiatry and clinical neurosciences. 2020;74(4):281.

20. Rahman MA, Hoque N, Alif SM, Salehin M, Islam SMS, Banik B, et al. Factors associated with psychological distress, fear and coping strategies during the COVID-19 pandemic in Australia. 
Globalization and Health. 2020;16(1):1-15.

21. Hetkamp M, Schweda A, Bäuerle A, Weismüller B, Kohler H, Musche V, et al. Sleep disturbances, fear, and generalized anxiety during the COVID-19 shut down phase in Germany: relation to infection rates, deaths, and German stock index DAX. Sleep medicine. 2020;75:350-3.

22. Aslam F, Awan TM, Syed JH, Kashif A, Parveen M. Sentiments and emotions evoked by news headlines of coronavirus disease (COVID-19) outbreak. Humanities and Social Sciences Communications. 2020;7(1):1-9.

23. Yousuf H, Corbin J, Sweep G, Hofstra M, Scherder E, van Gorp E, et al. Association of a Public Health Campaign About Coronavirus Disease 2019 Promoted by News Media and a Social Influencer With Self-reported Personal Hygiene and Physical Distancing in the Netherlands. JAMA network open. 2020;3(7):e2014323-e.

24. Almutairi KM, Al Helih EM, Moussa M, Boshaiqah AE, Saleh Alajilan A, Vinluan JM, et al. Awareness, attitudes, and practices related to coronavirus pandemic among public in Saudi Arabia. Family \& community health. 2015;38(4):332-40.

25. Zhao E, Wu Q, Crimmins EM, Ailshire JA. Media trust and infection mitigating behaviours during the COVID-19 pandemic in the USA. BMJ Global Health. 2020;5(10):e003323.

26. Tsai J-Y, Phua J, Pan S, Yang C-C. Intergroup Contact, COVID-19 News Consumption, and the Moderating Role of Digital Media Trust on Prejudice Toward Asians in the United States: CrossSectional Study. Journal of medical Internet research. 2020;22(9):e22767.

27. Olagoke AA, Olagoke 00 , Hughes AM. Exposure to coronavirus news on mainstream media: The role of risk perceptions and depression. British journal of health psychology. 2020;25(4):865-74. 